\title{
Prevalensi Skabiosis Pada Pasien Kucing Di Klinik Scotty Pet Care Mataram
}

\section{Prevalence scabiosis in cat patients at the scotty pet care mataram}

\author{
Eko Susanto $^{1)}$, Candra Dwi Atma ${ }^{25)}$, Alfiana Laili Dwi Agustin ${ }^{35)}$, Novarina Sulsia \\ Ista'In Ningtyas ${ }^{45}$ \\ ${ }^{1)}$ Division Research of Clinic Scotty Pet Care Mataram, ${ }^{2)}$ Division of Mikrobiology \\ and Parasitology, ${ }^{3)}$ Division of Veterinary Public Health, ${ }^{4}$ Divion of Anatomi and \\ Pathology Veteriner, ${ }^{5}$ Veterinary Medicine, Mandalika education University \\ *Corresponding author: ekosusanto@gmail.com
}

\begin{abstract}
Abstrak
Skabiosis merupakan penyakit kulit menular yang sering dijumpai pada hewan dan cenderung sulit disembuhkan. Penyakit ini disebabkan oleh tungau Sarcoptes scabiei atau Notoedres cati pada kucing. Skabiosis menyerang kucing pada semua tingkat usia. Kucing yang terinfeksi menimbulkan, alopecia,dermatitis, anemia, gangguan hipersensitivitas, dan ketidaknyaman bagi kucing. Selain itu dapat menular kepada manusia (zoonosis) penelitian dengan metode deskriptif ini bertujuan untuk mengetahui besar prevalensi skabiosis pada pasien kucing di Klinik Scotty Pet Care Mataram, jumlah sampel yang digunakan adalah 14 ekor kucing yang dipilih secara purposive sampling. Peneguhan diagnosa skabiosis dilakukan dengan 2 tahap : pemeriksaan terhadap gejala klinis dan pemeriksaan laboratoris. Pemeriksaan laboratoris hanya dilakukan pada sampel yang dengan gejala klinis skabiosis. Pemeriksaan sampel dilakukan menggunakan teknik scraping. Teknik scraping dilakukan dengan cara kerokan kulit diambil di area sekitar lesi kemudian diletakan pada object glass dan ditetesi $\mathrm{KOH}$ 10\% kemudian ditutupi dengan cover glass dan diperiksa dibawah mikroskop dengan pembesaran 400x. Hasil penelitian menunjukan positif 8 dari 14 sampel dengan prevalensi skabiosis pada pasien kucing di klinik scotty pet care mataram adalah $57 \%$.
\end{abstract}

Kata kunci : Prevalensi, skabiosis.

\section{Abstract (In English)}

Scabiosis is a contagious skin disease that is often found in animals and tends to be difficult to cure. This disease is caused by the Sarcoptes scabiei or Notoedres cati mite in cats. Scabiosis affects all types of cats at the age level. Infected cats develop, alopecia, dermatitis, anemia, hypersensitivity disorders, and discomfort to cats. In addition, it can be transmitted to humans (Zoonosis). This descriptive research method aims to determine the prevalence of scabiosis in cat patients at the Scotty Pet Care Mataram Clinic. The number of samples used was 14 cats selected by purposive sampling. Confirmation of the diagnosis of scabiosis is carried out in 2 stages: examination of clinical symptoms and laboratory examination. Laboratory examination is only performed on samples with clinical symptoms of scabiosis. Sample examination was carried out using scraping techniques. The scraping technique is done by taking skin scrapings in the area around the lesion then placing them on a glass object and dropping $10 \% \mathrm{KOH}$ then covering them with a glass cover and examining them under a microscope with 400x magnification. The results showed that 8 out of 14 samples were positive with the prevalence of scabiosis in cat patients in the scotty pet care Mataram clinic was $57 \%$.

Key Words : Prevlence, scabiosis. 


\section{Pendahuluan}

Skabiosis merupakan penyakit kulit menular yang sering dijumpai pada hewan dan cenderung sulit disembuhkan. Penyakit ini disebabkan oleh tungau Sarcoptes scabiei atau Notoedres cati pada kucing. Skabiosis menyerang kucing pada semua tingkat usia. Infestasi Notoedres cati pada kucing sangat menular dari satu kucing ke kucing lain. Kucing yang terinfeksi menimbulkan alopesia, dermatitis, anemia, gangguan hipersensitivitas, dan ketidaknyaman bagi kucing (Mossallnejad et al., 2011). Selain itu dapat menular kepada manusia (zoonosis) (Mading and Sopi, 2015).

Hewan di Indonesia yang sering menderita skabiosis adalah hewan ternak seperti kambing, babi, sapi, kelinci dan pets aminal (kucing dan anjing). Menurut hasil laporan Rumah Sakit Hewan Prof. Soeparwi Yogyakarta, pada JanuariAgustus 2012 didapatkan prevalensi Notoedres cati pada kucing sebanyak 3,7\% (Amalia dan Rohayati, 2013). Penelitian serupa dilakukan di klinik hewan di kabupaten Bogor pada kucing dengan kasus Notoedres cati 2,7\% (Siagian dan Fikri, 2019).

Penyakit Skabiosis merupakan salah satu faktor yang dapat menurunkan produktivitas hewan. Parasit bertahan hidup dalam tubuh hospes dengan memakan jaringan tubuh, mengambil nutrisi yang dibutuhkan dan menghisap darah hospes. Hal ini menyebabkan terjadinya penurunan bobot badan, pertumbuhan yang lambat, penurunan daya tahan tubuh dan kematian hospes. Hewan yang terinfeksi Skabiosis biasanya mengalami kekurusan sehingga mempunyai nilai jual yang rendah (Khan et al., 2008)

\section{Materi dan Metode}

Sampel yang digunakan pada penelitian ini yang terdapat di Klinik Scotty Pet Care Mataram sebanyak pasien kucing dalam kurun waktu 1 bulan pada bulan
Februari yang ada di Klinik Scotty Pet Care Mataram dengan cara purposive sampling. Kriteria kucing yang digunakan sebagai sampel adalah dengan ciri-ciri adanya alopesia beserta lesi pada bagian seperti telinga, kepala, dan ekor (Marvin, 2004). Sampel yanng diambil sebanyak 15 sampel. Metode pengambilan sampe yang digunakan adalah metode Purposive sampling pasien di Klinik Scotty Pet Care Mataram.

Pengambilan sampel dilakukan langsung dari bagian tubuh kucing yang terkena lesi seperti, telinga, kepala dan ekor dengan melakukan pengkerokan sampai berdarah menggunakan scapel tumpul kemudian diambil menggunakan cotton bud dan diletakan di plastik clip. Selanjutnya dibawa dan diperiksa ke Laboratorium parasitologi Fakultas Kedokteran Hewan Universitas Pendidikan Mandalika.

Pemeriksaan sampel dilakukan menggunakan teknik Scraping. Teknik Scraping dilakukan dengan cara kerokan kulit diambil di area sekitar lesi kemudian diletakan pada Object glass dan ditetesi $\mathrm{KOH} 10 \%$ kemudian ditutupi dengan cover glass. Selanjutnya diamati dibawah mikroskop pembesaran 100x kepembesaran 400x (Colville,.1991). Prevalensi Tungau Sarcoptes Scabiei atau Notoedres cati ditemukan pada penelitian ini akan mengacu pada buku Veterinary Parasitologi (Taylor et al., 2007).

\section{Hasil dan Pembahasan}

Berdasarkan hasil penelitian yang telah dilakukan terhadap 14 sampel kerokan kulit pada kucing, ditemukan 8 sampel positif terinfeksi Notoedres cati. Skabiosis dengan gejala yang menciri pada permukaan kulit yaitu keropeng, bersisik, alopesia, papula, hiperemi, dan kulit terlihat jelek pada bagian kepala, muka, telinga dan kaki. Notoedres cati berbentuk bulat, perisai dan striae halus dan berbentuk melingkar, tungkai pendek dan 


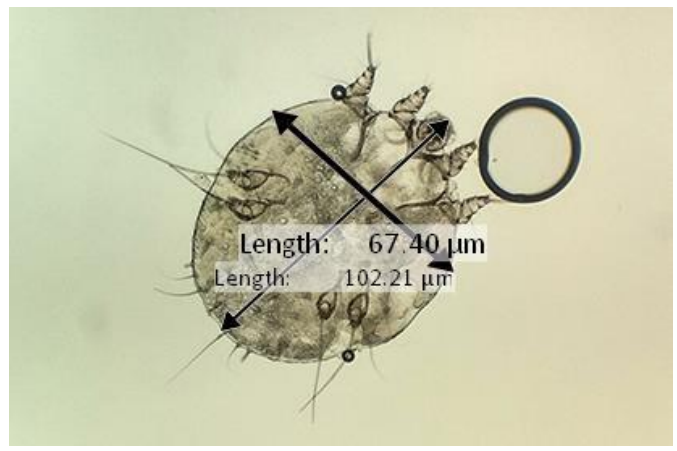

Gambar 1. Notoedres cati

Hasil jumlah prevalensi skabiosis pada pasien kucing di klinik scotty pet care mataram sebesar $57 \%$. Berdasarkan hasil pengamatan terhadap pasien kucing yang terinfeksi tungau Notoedres cati di Klinik Scotty Pet Care Mataram. Memperlihatkan daerah permukaan tubuh yang terinfeksi skabiosis ini adalah daerah kepala, muka, telinga, dan kaki. Penularan skabiosis terjadi secara kontak langsung baik antara hewan peliharaan yang satu dengan yang lain yang menderita skabiosis (Yunita, 2018).

Tabel 1 Hasil Pemeriksaan Notoedres cati di Klinik Scotty Pet Mataram

\begin{tabular}{c|c|c}
\hline No & Kategori & Hasil \\
\hline 1 & Jumlah positif & 8 \\
\hline 2 & Jumlah negatif & 6 \\
\hline
\end{tabular}

Gejala klinis pada kucing di klinik menunjukan adanya depresi pada kucing tersebut yaitu kucing tampak lesu, kurang nafsu makan, kulit tampak menebal, gatal-gatal dan hewan terlihat kurus, selain itu hewan terlihat menggesekgesekan daerah terinfeksi ke tiang kandang, menggaruk dan menggigit kulitnya secara terus-menerus. Menurut Rochiman (2010) gejala klinis skabiosis pada kucing serupa dengan kudis pada anjing, tetapi kerusakan umumnya terjadi pada kepala dan leher, biasanya mulai dari dahi, sekitar mata dan telinga. Infestasi disertai sisik abu-abu dan pengerasan serta penebalan kulit, umumnya terjadi pruritis.

Hewan yang terkena penyakit skabiosis harus segera diisolasi (diasingkan) dari hewan yang sehat untuk mencegah penyebaran penyakit secara kontak langsung. Kucing yang terinfeksi tidak diisolasi melainkan disatukan dengan hewan lainnya menjadi faktor penyakit skabiosis tersebut cepat menular ke kucing yang sehat (Amalia dan Rohayati, 2013). Prevalensi skabiosis pada pasien kucing di Klinik Scotty Pet Care Mataram sebesar 57\%. Angka ini dikatakan tinggi dibandingkan dengan penelitian sebelumnya dilakukan oleh (Siagian, 2019) di Rumah Sakit Hewan Kabupaten Bogor yang menunjukan angka prevalensi sebesar 2,7\%. Hasil analisis menunjukan tingkat prevalensi skabiosis pada pasien kucing di Klinik Scotty Pet Care Mataram cukup tinggi. Tingginya angka prevalensi pasien 
kucing di Klinik Scotty Pet Care Mataram, disebabkan beberapa faktor yaitu kurangnya kebersihan dalam perawatan kucing, sanitasi kandang dan lingkungan yang kurang baik, tempat yang lembab dapat menyebabkan tungau dapat bertahan hidup lebih dari 30 hari (Jensen dan Swift, 2006).

\section{Kesimpulan}

Berdasarkan uraian pembahasan diatas dapat disimpulkan bahwa Prevalensi skabiosis pada pasien kucing yang ditemukan di Klinik Scotty Pet Care Mataram yaitu 57\%.

\section{Ucapan Terima Kasih}

Terima kasih kepada semua pihak yang sudah membantu kelancaran artikel ilmiah ini.

\section{Daftar Pustaka}

Abu-Samra MT, Hago BED, Aziz MA and Awad FW 1981. Sarcoptic Mange in Sheep in the Sudan. Annals of Tropical Medicine and Parasitology 75: 639-645.

Alexander, J.O. 1984. Scabies: Arthropods and Human Skin. New York: Springer-Verlag. pp. $227-292$

Amalia, D dan Rohayati E.S 2013.Prevalensi scabies pada kucing di RSH Prof Soeparwi Yogjakarya. Pada Januari-Agustus 2013. Fakultas Kedokteran Hewan Universitas Gajah Mada

Bashofi AS, Soviana S, Ridwan Y. 2015. Infestasi pinjal dan deteksi Dypilidium caninum (Linnaeus) pada kucing liar di lingkungan kampus Institute Pertanian Bogor. Kecamatan Dramaga. Jurnal Entomologi Indonesia. 2(2):108114. ISSN:1829_1122

Budiantono, 2004.Kerugian Ekonomi Akibat Scabies dan Kesulitan Dalam Pemberantasannya. Prosiding Seminar Parasitologi dan Toksikologi Veteriner, Balai
Penyidikan dan Pengujian

Veteriner Regional VI: Denpasar

Budiharta, S. 2002. Kapita Selekta Epidemiologi Veteriner. Bagian Kesehatan Masyarakat Veteriner. Fakultas Kedokteran Hewan. Universitas Gadjah Mada. Yogyakarta.

Coville, J. 1991. Diagnosic Parasitology for Veterinary Techicians for public health. Boca Raton: CRC/Taylor and Francis. Pp. 362 Crompon, D.W.T. 2001.

David. 2002. Kapita Selekta Kedokteran. Bina Rupa Aksara: Jakarta

Diah Rodiah, 2001. Study Kasus Scabies Pada Kucing Di Rumah Sakit Hewan Jakarta. Fakultas Kedokteran Hewan : Institute Pertanian Bogor.

Djuanda, 2007.Ilmu Penyakit Kulit dan Kelamin. Edisi Kelima. Jakarta : Balai Penerbit FKUI

Done SH, Goody PC, Evans SA, Stickland NC. 2009. Color Atlas Of Veteriner Anatomy, The Dog and Cat, Ed ke-3. Missouri: Elsevier.

Firza, S, dan Hanna M, Skabies,2016 Bagian Parasitology,Fakultas Kedokteran Universitas Lampung, Majority/Volume V.

Foster Michael A, Stewart Nancy and Swift Jean. 2008. Cat Anatomy and Physiology. 4-h Cat Project - unit 3- em4289e.Washington University Extension.

Ghubash R, 2006. Parasitic Miticidal Therapy. Clin Tech Small Amin Pract21: 135-144

Iskandar Tolibin, 2000. Masalah Scabies

Pada Hewan dan Manusia Serta

Penanggulangannya. Wartazoa

Vol. 10 No. 1 Balai Penelitian Veteriner: Bogor.

Jensen, R. And B. L. Swift. 2006. Disease of Sheep. 2 years Eds. Lea \& Febiger.Philadelphia

Kertayadnya, I. G., D. H. A. Unruh, M. Gunawan dan K. S. Adhiputra. 
2003. Scabies, Epizootiologi, Pengobatan dan Perkiraan Kerugian Ekonomi. Dalam Laporan Tahunan Hasil Penyelidikan Penyakit Hewan di Indonesia Periode Tahun 20012002. Direktorat Kesehatan Hewan. Derektorat Jendral Peternakan Dapertemen Pertanian. Jakarta.

Kemp DJ, 1989. Walthon SF, Harumal P, Currie BJ, 2002. The Scourge of Scabies.

Khan MK, Sajid MS, Khan MN, Iqbal Z and Iqbal MU. 2008. Prevalence, effects of treatment on productivity and cost benefit analysis infive districts of Punjab, Pakistan. Res Vet Sci. 87: 70-75

Kral, F. 1953. Veterinary Dermatology. J.B. Lippincott Company. Philadelphia.325 hal.

Kusuma, W. 2000.Kucing dan Penyembuhan Penyakit. Batam: Interaksa. Leuvine, N. D. 2000. Parasitologi Veteriner. Gadjah Mada University Press,Jogyakarta.

Mading M, Sopi II. 2015. Aspect of Epidemiology Studies Scabies in Human.2(2):9

Morsallanejad B, Alborzi AL, Katvandi N. 2011. A survey on ectoparasite infestation in companion dogs of ahvaz Distric, Sout-West Of iran. Journal Atrhopod-Bone Dis. 6(1):70-78

Rochiman .S, Hastutiek P, Sunasrso A, dan Yunus M. 2010. "Ilmu Penyakit Anthropoda Veteriner". Departemen Parasitologi, Fakultas Kedokteran Hewan, Universitas Airlangga, Surabaya 2010.

Plumb, D. C. 2008. Veterinary Drug Hnadbook $6^{\text {th }}$ Editoin.Wisconism : Black Well Publishing.

Safar. 2009. Parasitologi Kedokteran Protozologi Helminthologi Entomologi.Bandung : Yrama Widya.

Selvin S. 2004. Statistical Analysis Of
Epidemiology Data. London (UK): Oxfo University Pres. Wilayah Sibermas Kecamatan Fatuleu Kabupaten Kupang.

Siagian, T.B, dan Fikri FH. 2019. Infestasi Ektoparasit pada kucing di KlinikHewan Kabupaten Bogor. IPB University

Soeharsono, 2007.Penyakit Zoonotik Pada Anjing dan

Kucing. Yogyakarta : Kanisius.

Soulsby, E. J. L. 1982. Helminths, Arthropods and Protozoa of Domesticated Animals. 7 th Eds. Bailliere, Tindal and Casseli. London.

Subronto, 2006.Penyakit Infeksi Parasit dan Mikroba Pada Anjing dan Kucing.Yogyakarta : Gadjah Mada University Pers.

Sudiyanto, 2012. Hubungan Personal hygiene dan sanitasi lingkungan dengan scabies di wilayah kerja puskesmas lingkar timur kota Bengkulu: Stikes Dehasen

Taylor M. A, Coop R. L and Wall Richard L. 2007.Veterinary Parasitology Third Editoin.Australia Black Well Publishing.

Taylor MA and RL Coop. 2007 Veteriner Parasitology.Blackwell

Publishing.Oxford, UK.

Tuner DC, Bateson P. 2000. The Domestic Cat, The Biology of Its Behaviour. Camridge: Cambridge University Pr.

Upik K.H, Dwi J.G, Susi S, Supriyono 2017. Atlas Entomology Veteriner. IPB Science Techno Park. Ektoparasit Pada Anjing dan Kucing 105.

Urquhart, G.M., J. Armour, H. Duncan, A.M. Doon and F.W. Jenning. 1989. Veterinary Parasitology. Long Man Scientific and Technical. New York. pp. 184 187.echnical, London

Urquhart, G.M.Armour, J., Duncan, J.L.,et al.(1987) Veterinary 
parasitology. Longman Scientific and $\mathrm{T}$

Wall Richard and David Shearer. 2001. Veterinary Ectoparasites : Biology, Patology and control $2^{\text {nd }}$ Edition. Iota State University : USA.

Yunita S, Gustiana R, Anas E. 2018. Faktor-Faktor yang berhubungan dengan kejadian skabies diwilayah kerja Puskesmas Lubuk Buaya Kota Padang tahun 2015. Jurnal Kesehatan Andalas

Zasac AM and Conboy GA. 2012.Veteriner Clinical Parasitology. $8^{\text {th }}$ ed. John Wiley and Sons, Inc. UK . 